\title{
Enhancement of Groundnut Productivity by Inoculation with Bradyrhizobium and Rizobacteria under Different Levels of Compost in Sandy Soils
}

\author{
T.Y. Rizk, E.M. Soliman*, F.E.EL-Araby ${ }^{* *}$ and Hala \\ A.M.EL-Sayed ${ }^{* *}$ \\ Dept. of Agronomy, Faculty of Agric., Ain Shams University; \\ *Dept. Agric. Sciences., Inst. of Environmental Studies and \\ Researches and ${ }^{* *}$ Dept. Agric Scinces, Higher Inst. for Agric. \\ Co- operation, Cairo, Egypt.
}

7 WO FIELD experiments were conducted at the Agricultural Research Farm of the Higher Institute for Agriculture Cooperation during the two successive seasons of 2008 and 2009. These experiments aimed to study the effect of inoculation with Bradyrhizobium spp. either alone or in combination with (Pseudomonas fluorescens) on yield and some yield components under different levels of compost using drip irrigation system.

Results showed that plants inoculated with Bradyrhizobium spp. only or in combination with rhizobacteria exhibited significant increases in pod yield and some yield components as compared with the uninoculated plants.

The response of groundnut, yield and yield components to elevating the organic fertilizer rate was positively significant, higher rate of compost 15-ton/fed (1hectare $=2.4$ feddan) showed higher values of all tested traits in both seasons.

Spraying groundnut plants with humex increased significantly all tested traits compared with those without humex in both seasons.

The effect of the first and second orders interactions on yield and yield components were significant.

Keywords: Groundnut, Bradyrhizobium, Rhizobacteria, Compost, Sandy soil.

Peanut (Arachis hypogaea L.) is considered to be one of the most important source of edible oil crop in the world. The seeds characterized with high nutritive value for humans. Groundnut seeds contain high oil content $(50 \%)$, which is utilized in different industries, in addition to $26-28 \%$ protein, $20 \%$ carbohydrates and 5\% fiber (Fageria et al., 1997). Groundnut like other legumes forms symbiosis relationship with rhizobia. 
Symbiotic nitrogen fixation by legumes plays an important role in sustaining crop productivity and maintaining the fertility of the semi-arid lands (Desoky et al., 2011).

Egyptian soils are very poor in organic matter content, which does not exceed $2 \%$ and often less than $1 \%$, due to arid climate and dominancy of basic soil conditions. Moreover, the sustainable supply of organic matter to soils is very essential, particularly under the intensive cropping system of Egyptian agriculture.

Over the last few years, a diverse array of beneficial rhizobacteria has been shown to promote plant growth. The mechanism by which these rhizobacteria enhance plant growth is not clear, but it is postulated that they may: (a) produce of secondary metabolites such as antibiotics, cyanide and hormonelike substances, (b) produce of siderophores, (c) fix dinitrogen (d) increase phosphate solubilization, (e) enhance mineral uptake and/or (f) antagonistic to soil borne root pathogens (Vargas et al., 2009).

Enhancement of nodulation and biological nitrogen fixation of legumes by co-inoculation with plant growth promoting (PGP) microorganisms are becoming a practical way to improve nitrogen availability in sustainable agricultural production system (Bai et al., 2002 and Abdel-Wahab et al., 2008).

The present work aimed to study the effect of co-inoclation with Bradyrhizobium and rhizobacteria." Pseudomonas" under different levels of compost on yield and some yield components of groundnut in sandy soil.

\section{Materials and Methods}

The present work was conducted to investigate the effect of biofertilizations on groundnut productivity under deferent levels of compost in sandy soil.

\section{Materials}

Groundnut seeds

Groundnut seeds variety (Ismaeilia 1 ) were kindly provided from the Field Crops Research Institute, Agricultural Research Center (ARC), Giza, Egypt.

\section{Organic fertilizer}

Compost : Compost was used as a source of organic materials . It was obtained from Moshtohor Factorty in Qaluobeia Governorate, its main chemical and biological traits are shown in Table 1. Compost was applied at the following two levels, i.e. 8 and 15 ton/feddan.

Canda Humex: Canda humex is an extract from humic, fulvic and active humein, applied at a rate of $2 \mathrm{~L} /$ fed splited into three equal doses applied at 15 , 30,45 days from sowing as a foliar application.

Egypt. J. Agron . 34, No.2 (2012) 
TABLE 1. Chemical analysis of the compost used during 2008 and 2009 seasons.

\begin{tabular}{|l|c|c|}
\hline \multirow{2}{*}{ Characterization } & \multicolumn{2}{|c|}{ Seasons } \\
\cline { 2 - 3 } $\mathrm{pH}$ & $\mathbf{2 0 0 8}$ & $\mathbf{2 0 0 9}$ \\
E.C(ds/m) & 7.71 & 7.62 \\
Organic-C (\%) & 4.68 & 3.81 \\
Total-N (\%) & 20.18 & 19.89 \\
C/N ratio & 1.31 & 1.26 \\
Organic matter \% & 15.40 & 15.78 \\
Total -P\% & 34.71 & 34.21 \\
Total -K\% & 0.78 & 0.59 \\
Total Soluble-N (ppm) & 1.75 & 1.68 \\
Available- P (ppm) & 143.70 & 132.8 \\
Available-K (ppm) & 163.80 & 146.7 \\
Dehydrogenase activity $(\mu \mathrm{g}$ TPF/g) & 574.80 & 518.6 \\
Seed germination index for cress at $48 \mathrm{hr}$ & 90.81 & 90.81 \\
\end{tabular}

\section{Bacterial inocula}

Bradyrhizobium sp. (strain USDA 3456) and Pseudomonas fluorescens (strain IFO 2034) were kindly obtained from the Biofertilizers Production Unit, Agric. Microbiol. Dept., Soils, Water and Environ. Res. Inst. (SWERI), ARC,Giza, Egypt.

Bradyrhizobium was cultured in a yeast extract mannitol broth medium (Vincent, 1970) and Pseudomons was grown in king's medium B (Atlas, 1995). Cultures were incubated at $28^{\circ} \mathrm{C}$ for three days on a rotary shaker unit. Population density reached to $10^{9} \mathrm{cfu} / \mathrm{ml}$ culture. Powdered vermiculite supplemented with $10 \%$ Irish peat was packed into polyethylene bags (200 g carrier per bag), then sealed and sterilized with gamma irradiation $(5.0 \mathrm{x} 10$ rads). Each bacterial culture (120 $\mathrm{ml}$ of $\log$ phase growing culture) was injected into a sterilized carrier to satisfy $60 \%(\mathrm{w} / \mathrm{w})$ of the carrier mixture and mixed thoroughly.

\section{Methods}

Field experiments

Two field experiments were conducted under drip irrigation system at the Experimental Station, Agricultural Research Higher Institute for Agriculture Cooperation during the two successive summer seasons of 2008 and 2009. These experiments aimed to study the effect of inoculation with Bradyrhizobium spp. either alone or combined with plant growth-promoting rhizobacteria (PGPR) on nodulation, growth, yield and yield components of groundnut under different levels of organic fertilizer (compost and Canda humex) in sandy soil. The physical and chemical properties of the experimental soil are presented in Table 2. 
TABLE 2. Physical and chemical properties of soil used in the first and second season .

\begin{tabular}{|c|c|c|c|c|}
\hline \multirow[b]{2}{*}{ Property } & \multicolumn{2}{|c|}{$1^{\text {st }}$ Season } & \multicolumn{2}{|c|}{$2^{n d}$ Season } \\
\hline & $\begin{array}{c}\text { 15-cm } \\
\text { deep }\end{array}$ & $\begin{array}{c}\text { 30-cm } \\
\text { deep }\end{array}$ & $\begin{array}{c}\text { 15-cm } \\
\text { deep }\end{array}$ & $\begin{array}{c}\text { 30-cm } \\
\text { deep }\end{array}$ \\
\hline $\begin{array}{l}\text { Particle size distribution (\%) } \\
\text { Coarse Sand } \\
\text { Fine Sand } \\
\text { Silt } \\
\text { Clay } \\
\text { Texture } \\
{\text { Bulck density }\left(\mathrm{g} / \mathrm{cm}^{3}\right)}_{\mathrm{CaCO}_{3}(\%)} \\
\text { Water Holding capacity }(\%) \\
\text { pH (soil paste) } \\
\text { EC (dS/m) }\end{array}$ & $\begin{array}{c}11.30 \\
74.95 \\
9.75 \\
4.00 \\
\text { Sandy } \\
1.28 \\
1.84 \\
23.00 \\
7.50 \\
0.24\end{array}$ & $\begin{array}{c}11.14 \\
76.66 \\
8.58 \\
3.62 \\
\text { Sandy } \\
1.33 \\
1.74 \\
24.0 \\
7.65 \\
0.43\end{array}$ & $\begin{array}{c}12.10 \\
74.30 \\
8.70 \\
4.90 \\
\text { Sandy } \\
1.30 \\
1.68 \\
24.20 \\
7.46 \\
0.31\end{array}$ & $\begin{array}{c}11.90 \\
75.40 \\
8.50 \\
4.20 \\
\text { Sandy } \\
1.32 \\
1.62 \\
24.80 \\
7.62 \\
0.52\end{array}$ \\
\hline $\begin{array}{l}\text { Soluble cations and anions }(\mathbf{m e q} / \mathbf{L}) \text { : } \\
\mathrm{Ca}^{++} \\
\mathrm{Mg}^{++} \\
\mathrm{Na}^{+} \\
\mathrm{K}^{+} \\
\mathrm{CO}_{3}{ }^{+} \\
\mathrm{HCO}_{3}^{-} \\
\mathrm{Cl}^{-} \\
\mathrm{SO}_{4}=\end{array}$ & $\begin{array}{l}0.88 \\
0.19 \\
1.06 \\
0.32 \\
--- \\
1.00 \\
0.35 \\
1.10\end{array}$ & $\begin{array}{l}0.72 \\
0.45 \\
2.26 \\
0.71 \\
--- \\
1.10 \\
0.70 \\
2.34\end{array}$ & $\begin{array}{l}0.82 \\
0.24 \\
1.16 \\
0.42 \\
---- \\
1.20 \\
0.41 \\
1.03\end{array}$ & $\begin{array}{l}0.76 \\
0.49 \\
2.42 \\
0.98 \\
--- \\
1.36 \\
0.79 \\
2.50\end{array}$ \\
\hline $\begin{array}{l}\text { Total soluble- } \mathrm{N} \mathrm{mg} \mathrm{kg}^{-1} \\
\text { Available }-\mathrm{P} \mathrm{mg} \mathrm{kg} \\
\text { Available }-\mathrm{K} \mathrm{mg} \mathrm{kg} \\
\text { Total }-\mathrm{N}(\mathrm{N} \%) \\
\text { Organic matter }(\%)\end{array}$ & $\begin{array}{c}15.00 \\
3.40 \\
88.00 \\
0.024 \\
0.42\end{array}$ & $\begin{array}{c}20.0 \\
5.0 \\
96.0 \\
0.025 \\
0.33 \\
\end{array}$ & $\begin{array}{c}22.00 \\
4.300 \\
92.50 \\
0.026 \\
0.40 \\
\end{array}$ & $\begin{array}{c}26.00 \\
6.60 \\
98.60 \\
0.027 \\
0.30 \\
\end{array}$ \\
\hline $\begin{array}{lll}\text { *DTPA-extractable. } & \mathrm{Fe} & \mathrm{mg} \mathrm{kg}^{-1} \\
& \mathrm{Mn} & \mathrm{mg} \mathrm{kg}^{-1} \\
& \mathrm{Zn} & \mathrm{mg} \mathrm{kg}^{-1} \\
& \mathrm{Cu} & \mathrm{mg} \mathrm{kg}^{-1}\end{array}$ & $\begin{array}{l}1.07 \\
0.55 \\
0.25 \\
0.05\end{array}$ & $\begin{array}{l}1.20 \\
0.60 \\
0.20 \\
0.03\end{array}$ & $\begin{array}{l}1.22 \\
0.52 \\
0.31 \\
0.05\end{array}$ & $\begin{array}{l}1.31 \\
0.66 \\
0.29 \\
0.04\end{array}$ \\
\hline
\end{tabular}

* DTPA: Diethylene triamine Penta Aacetic acid

The following treatments were applied

1-Uninoculated plants (control)

2-Inoculation with Bradyrhizobium sp.

3-Inoculation with Bradyrhizobium sp. and PGPR (Pseudomonas fluorescens).

The above biofertilizer treatments were carried out in presence of two levels of compost, i.e., 8 and 15-ton/feddan applied 15 days before sowing with or without the organic liquid humex.

Groundnut seeds were inoculated with gamma irradiated vermiculite-based inoculant of each bacterium at a rate of $300 \mathrm{~g} / 40 \mathrm{~kg}$ seeds using Arabic gum solution (16\%) as addhisive agent.

Egypt. J. Agron . 34, No.2 (2012) 
The experimental design to split-split plot with three replicates. The main plots included compost levels and the organic liquid humex represents the sub plots, whereas biofertilization treatments were assigned to the sub sub plots. Plot area was $10.5 \mathrm{~m}^{2}$ (1/400 fed).

All plots received the recommended doses from superphosphate $(15.5 \%$ $\left.\mathrm{P}_{2} \mathrm{O}_{5}\right)$ at a rate of $200 \mathrm{~kg} / \mathrm{fed}$ and potassium sulfate $\left(48 \% \mathrm{~K}_{2} \mathrm{O}\right)$ at a rate of 50 $\mathrm{kg} / \mathrm{fed}$. Nitrogen fertilizer was applied at a rate of $20 \mathrm{~kg} \mathrm{~N} / \mathrm{fed}$ in the form of ammonium sulphate $(20.5 \% \mathrm{~N})$ after 15 days from planting as activator dose.

At harvest, random plant samples of ten guarded plants each was collected from each plot to determine the following traits:

1 -Number of pods/plant.

2-Weight of 100- pods (g).

3-Weight of 100 -seeds (g).

The middle three rows of each plot with $3 \mathrm{~m}^{2}$ area were harvested to determine the following traits:

1- Pod yield (ardab/fed).

2- Shelling percentage (seed weight/pod weight) $\times 100$.

$* 1$ ardab $=75 \mathrm{~kg}$ seeds peanut

$* 1$ hectare $=2.4$ feddan

Methods of analyses

- Soil and compost properties were determined according to Piper (1950) and Page et al.(1982).

- Seed crude protein percentage was calculated by N\% X 6.25 (A.O.A.C., 1990)

- Oil \% was determined according to A.O.A.C. (1990)

Statistical analysis

The obtained data were subjected to the proper Analysis of Variance (ANOVA) and L.S.D. test was used to compare the treatment means according to the procedures outlined by Snedecor \& Cochran (1980) using MSTAT computer program.

\section{Results and Discussion}

Number of pods, weight of 100-pods and seed index

Number of pods, weight of 100- pods and weight of 100- seeds as affected by co-inoculation with both Bradeyrhizobium and rhizobacteria under different levels of compost are presented in Table 3. Results elucidated that, inoculation of peanut plants with Bradyrhizobium only or combined with Pseudomonas gave significant increases in number of pods 15.31 and $38.94 \%$ in the first season, respectively. The corresponding increases in the second season were 16.89 and $23.86 \%$, respectively. However, this co-inoculation were more detectable under sandy soil conditions due to the low nutrient content of that soil. These results are in accordance with those obtained by Gupta et al. (2003) and Dey et al. (2004) . 


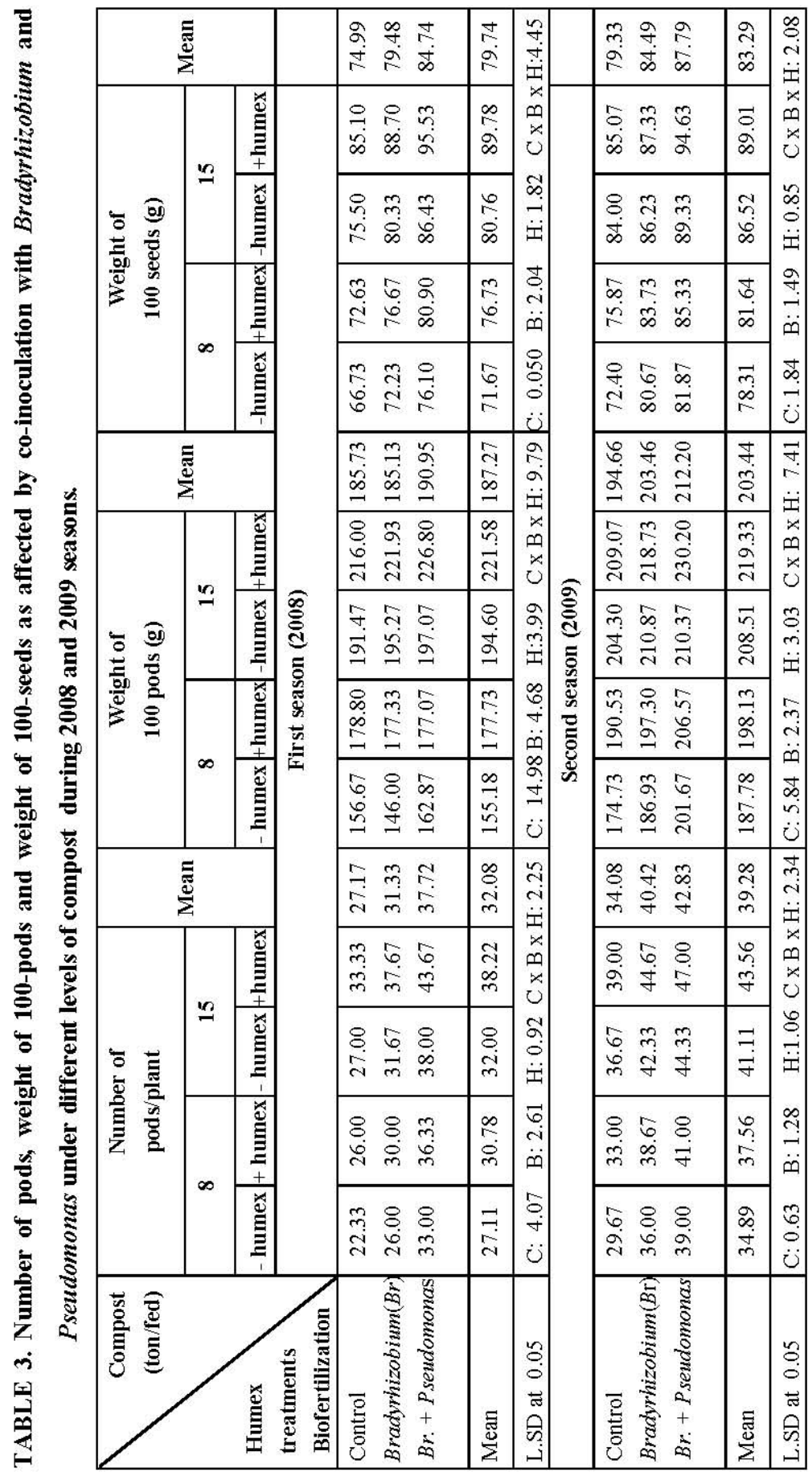

Egypt. J. Agron . 34, No.2 (2012) 
Regarding the effect of compost, data in Table 3 revealed that applying compost up to 15 ton/fed caused significant increases in number of pods, weight of 100- pods and weight of 100- seeds over the other level of compost (8-ton/fed). These increases were 21.70 and $16.87 \%$ in number of pods, 20.2 and $10.89 \%$ in weight of 100- pods and 14.92 and $9.74 \%$ in 100- seeds weight in the first and second seasons, respectively. The distinct role of the organic materials in improving peanut productivity in sandy soil, might be due to the improving of soil fertility and plant nutritional status that support plant health growth (Abdel-Wahab et al., 2009 ).

Owing to the effect to humex, data in Table 3 indicated that number of pods, weight of 100- pods and weight of 100- seeds /plant increased with spraying peanut plants by humex. These increases were 16.71 and $6.74 \%$ in number of pods, 14.16 and $5.33 \%$ in weight of 100 -pods and 9.24 and $3.53 \%$ in weight of 100- seed over the non-sprayed plants in the first and second seasons, respectively. These results are in accordance with those of by EL-Ghamry et al. (2009) , who found that number of pods/plant and weight of 100- seeds increased along with the application of humic acid.

The interaction effect between inoculation and rates of compost are shown in Table 3. The highest values of number of pods/plant, weight of 100 pods and weight of 100- seeds were due to the treatment received inoculation with mixture strains (Bradyrhizobium + Pseudomonas) combined with 15-ton compost/fed in both seasons, respectively. The promotive effect of compost might be magnified by presence of rhizobacteria, which enhance nodulation and nitrogen fixation resulting in higher productivity of peanut. The synergistic effect of bio-organic fertilization on legumes productivity in newly reclaimed soils was confirmed by Abdel-Hafez \& Abo EL-Soud (2007).

Results in Table 3 revealed that the highest values of number of pods (38.22 and 43.56), weight of 100 pods (221.58 and 219.33) and weight of 100- seeds ( 89.78 and 89.01) recorded in peanut plants treated with 15 -ton compost/fed foliarad with humex. These results are mostly in agreement with those of Saruhan et al. (2011). They demonstrated that humic acid compounds may have various biochemical effects either at cell wall, membrane level or in the cytoplasm, including the increases of photosynthesis and respiration rates in plants, enhanced protein synthesis and plant hormone-like activity and consequently enhanced the growth and productivity.

Data in Table 3 also showed that the interaction effect between biofertilizer and foliar application of humex had significant effect on some harvest traits , in both seasons. The highest values number of pods/plant, weight of 100-pods and weight of 100- seeds were achieved with the mixture strains (Bradyrhizobium + Pseudomonas) combined with humex. In fact, PGPR (Pseudomonas) have been shown to greatly improve the productivity and quality of many legumes, when coinoculated with rhizobia. These results could be attributed to the improvement of the moisture retention and nutrient supply potentials of sandy soils after humic substances application (Sugaya \& Sivasamy, 2006). In this concern, Saruhan et al. (2011) reported that organic materials (i.e., humic substances) treatments increased the yield and yield components of treated plants. 
Furthermore, data in Table 3 showed that the interaction effect between compost, biofertilizer inoculation and foliar application of humex had significant effects on yield and its components. The maximum number of pods/plant (43.67 and 47.00), weight of 100-pods (22.68 and 230.2) and weight of 100-seeds were achieved when peanut plants were fertilized with compost at a rate of 15ton/fed combined with dual inoculation of rhizobacteria and foliarad with humex. These results could be attributed to the availability of more $\mathrm{N}_{2}$ fixation due to biofertilizer application, the production of growth regulators substances such as indole acetic acid, gibberellins, pyridoxine and others, which stimulate plant growth and subsequently affect peanut yield and its attributes.

\section{Pods yield and shelling percentage}

The effect of inoculation with Bradyrhizobium associated with rhizobacteria on pods yield and shelling percentage is given in Table 4. Results showed that irrespective of organic fertilization, the uninoculated plants recorded the lowest values of pods yield (12.18 and $15.08 \mathrm{ardab} / \mathrm{fed})$ and shelling percentages (52.38 and 55.83) in both seasons, respectively. The maximum pods yield (16.97 and $19.96 \mathrm{ardab} / \mathrm{fed})$ and shelling percentage (61.00 and 63.64) were due to the inoculation with Bradyrhizobium + Pseudomonas followed by inoculation with Bradyrhizobium, which recorded pods yield of 14.79 and $17.88 \%$ ardab/fed and shelling percentages of 59.28 and 61.46 in both seasons, respectively. This synergistic effect of rhizobacteria on peanut yield are due to their ability to enhance the nodulation development that resulted in various enhances the production of substances like-hormones, siderophores, phosphate solubilization. These led to increase the nutrients uptake through increasing the root perforation. (Dilleep Kumar et al., 2001 and Tilak et al., 2005 ).

Concerning the effect of compost rates, results showed that high compost rates caused significant increases in pods yield and shelling\% in both tested seasons. The beneficial effect of such organic amendment incorporated into soil on peanut yield may be due to the regulation of soil temperature, conservation of moisture and improvement in humic content of the soil, which are important factors in increasing the number of microfolora and its activity and hence greater nutrients availability . (Abdel-Wahab et al., 2007 and EL-Kramany et al., 2007 ).

Data in Table 4 indicated that humex foliar spray increased significantly pods yield by 8.83 and $8.95 \%$ and shelling by 3.19 and $4.04 \%$ over the nonsprayed plants (control) in both seasons, respectively. EL-Ghamry et al.(2009) reported that the increment in growth parameters and yield may be due to that humic acid is extremely important component because it constitutes a stable fraction of carbon, thus regulating the carbon cycle and release of nutrients, including nitrogen, phosphorus and sulfur, which reduced the inorganic fertilizer needed for plant growth. Also, Shehata \& EL-Helaly (2010) showed that humic substances increased the yield of corn, oats, tobacco roots, soyabeans, peanut,clover marigold, pepper, strawberry and snap beans. 
ENHANCEMENT OF GROUNDNUT PRODUCTIVITY...

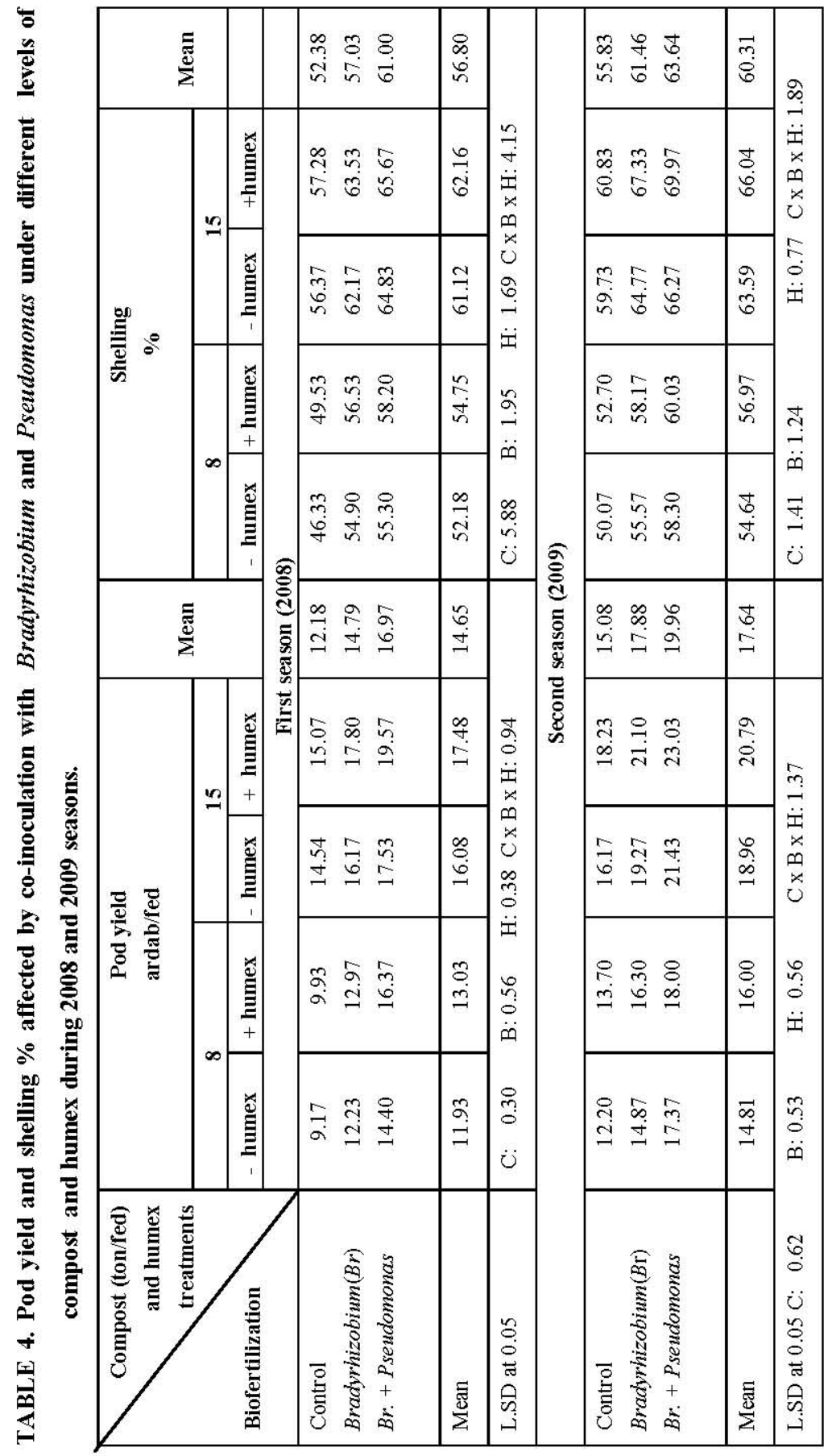

Egypt. J. Agron . 34, No.2 (2012) 
The interaction effect between biofertilization treatments and compost levels was significant in both growing seasons (Table 4). The highest values of pods (18.55 and $22.23 \mathrm{ardab} / \mathrm{fed}$ ) and shelling percentage (65.25 and 68.12) in both seasons were obtained by peanut plants inoculated with Bradyrhizobium plus Pseudomonas along with 15 ton/fed compost. This synergistic effect of rhizobacteria on peanut yield could be attributed to $\mathrm{N}_{2}$ fixation and/or production of growth promoting substances such as auxin, gibberillins and cytokinins, which positively affect plant growth. The present results are in harmony with those reported by Abdel Wahab et al. (2007) and EL-Sawy et al. (2006) who found that co-inoculation with Bradyrhizobium and rhizobacteria caused significant increases in yield and yield components of groundnut plants.

The interaction effect between biofertilizer and foliarad with humex had significant effect on pods yield/fed and shelling \% in both seasons (Table 4). The highest values of these traits were achieved by peanut plants inoculated with mixture of strains (Bradyrhizobium + Pseudomonas) combined with humex. These results could be attributed to the improvement of the moisture retention and nutrient supply potentiality of sandy soils after humic substances application (Sugaya \& Sivasamy, 2006). In this concern, Saruhan et al. (2011) reported that organic materials (i.e., humic substances) treatments increased the yield and yield components.

Meanwhile, the interaction effect between compost rates, biofertilizer inoculation and foliar application of humex had significant effects on pods yield and shelling percentages (Table 4). The maximum values of pods yield (19.57 and $23.03 \mathrm{ardab} / \mathrm{fed}$ ) and shelling percentages (65.67 and 69.97) were achieved when peanut plants were fertilized with compost at a rate of 15-ton/fed combined with dual inoculation of rhizobacteria and foliar application of humex. These results could be attributed to more $\mathrm{N}_{2}$ fixation due to biofertilizer application, the production of growth regulators substances such as indol acetic acid, gibberellins, pyridoxine and others, which stimulate plant growth and subsequently affect groundnut yield and its attributes. Similar observations were reported by EL-Ghamry et al. (2009).

\section{Protein and oil percentages of groundnut seeds}

The effect of inoculation with Bradyrhizobium singly or combined with Pseudomonas under different levels of compost on protein and oil percentages of peanut seeds is given in Table 5. Results indicated that the highest crude protein content of 25.13 and $25.94 \%$ and oil percentages of 47.76 and 48.82 recorded by the plants inoculated with Badyrhizobium + Pseudomonas followed by those inoculated with Bradyhirzobium, which recorded 23.97 and $24.90 \%$ of crude protein and 47.03 and $48.06 \%$ of oil in both seasons, respectively. These results are in agreement with those of EL-Sawi et al. (2006) and Mekhemar et al. (2007) who showed that inoculation with Bradyhirzobium increased in biomass, seed and protein yields over the uninoculated control. 
ENHANCEMENT OF GROUNDNUT PRODUCTIVITY...

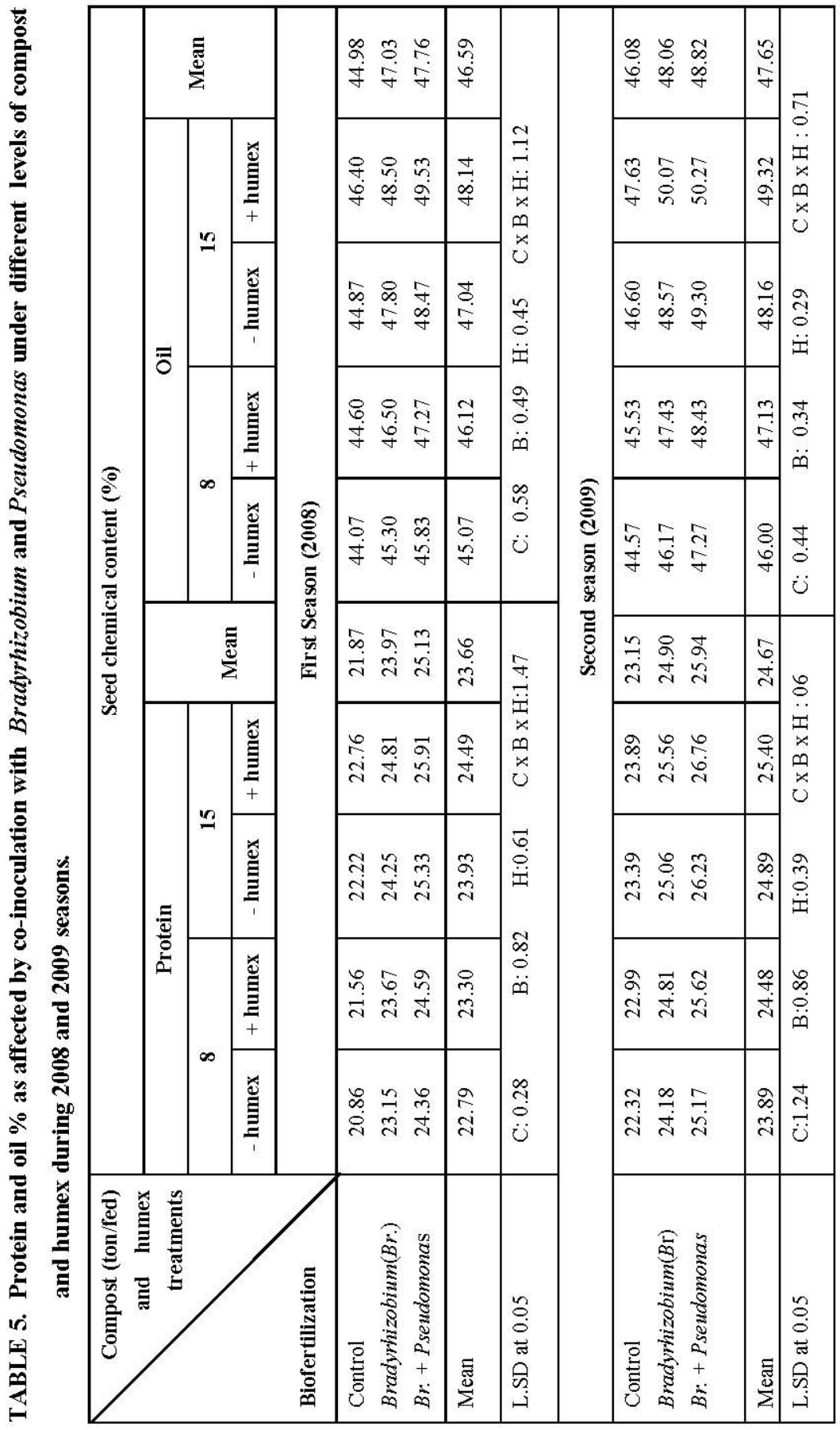

Egypt. J. Agron . 34, No.2 (2012) 
Regarding the effect of compost, data in Table 5 revealed that increasing the level of compost up to 15-ton/fed caused significant increases of protein and oil percentages compared to the other level of compost in both seasons. These increases were 5.03 and $4.01 \%$ in protein and 4.39 and $4.66 \%$ in oil in both seasons, respectively. These results are similar to those obtained by EL-Kramany et al. ( 2007), who found that the addition of high level of compost significantly increased the protein and oil percentages.

Data in Table 5 indicated that peanut seeds protein and oil percentages increased by spraying plants with humex. These increases were 2.31 and $2.26 \%$ in protein and 2.32 and $2.44 \%$ in oil over the non-sprayed plants in both seasons, respectively. In this concern Ali \& Mostafa (2009) found that applying humic acid gave the highest values of pods yield/fed, protein and oil percentages of seeds.

Table 5 shows the effect of the interaction between compost and biofertilization treatments on protein and oil contents of peanut seeds. Results confirmed again the superiority of using 15 ton/fed compost in combination with the mixture of bacterial inoculation treatment. The corresponding higher percentages of seed crude protein were 25.62 and 26.50 and oil (49.00 and 49.78 ) in both seasons, respectively. These results are in agreement with those obtained by EL-Sawi et al. (2006).

Results also revealed that, the interaction effect between compost and humex on protein and oil percentages were significant except for protein percentage in the first season (Table 5). The highest percentages of protein of 24.49 and 25.40 and oil of 48.14 and 49.37 were achieved when peanut plants fertilized with 15 ton compost/fed combined with humex. These results are in accordance with those obtained by Ali \& Mostafa (2009) and Saruhan et al .(2011) who showed that application of organic materials increased the concentration of crude protein and oil\% in seeds.

Data in Table 5 also showed that the combined effect of inoculation and foliar spray with humex on protein and oil percentages. The available results confirmed again the superiority of dual inoculation of Bradyrhizobium + Pseudomonas along with humax foliar spray, which recorded the highest values of protein percentages (25.42 and 26.18) and oil percentages (48.40 and 49.35) in both seasons, respectively. These results are in agreement with those obtained by Ali \& Mostafa (2009) who found that applying humic substances combined with biofertilizer recorded the highest values of protein and oil percentages.

The interaction effect between compost rate, biofertilizer inoculation and foliar application with humex significantly increased protein and oil percentages in both seasons (Table 5). The highest percentages of protein (25.91 and 26.76) and oil (49.53 and 50.27) were obtained by applying 15-ton compost/fed combined with dual inoculation with Bradyrhizobium and Pseudomonas and foliar spray with humex in the $1^{\text {st }}$ and $2^{\text {nd }}$ seasons, respectively. The response of protein and oil contents to the tested three factors were not the same.

Egypt. J. Agron . 34, No.2 (2012) 


\section{References}

Abd El-Hafez, G.A. and Abo El-Soud, A.A. (2007) Response of two soybean cultivars to different levels of organic fertilizer (compost). J. Agric. Sci. Mansoura Univ. 32, $8575-8588$

Abd El-Wahab, A.F.M., Badawi, F.Sh.F., Mekhemar, G.A.A. and El-Farghal, W.M. (2007) Effect of enriched compost tea and rhizobacteria nodulation, growth and yield of chickpea in sandy soil. Minufiya J.Agric. Res. 32, 297-321.

Abd El-Wahab, A.F.M., Biomy, A.M.M. and El-Farghal, W.M. (2009) Cocomposting of plant residues and their utility with micronutrients to enhance productivity of faba bean-Rhizobium symbiosis under sandy soil conditions. Egypt. J. Appl.Sci. 24, 343-368.

Abd El-Wahab, A.F.M., Mekhemar, G.A.A., Badawi, F.Sh.F. and Shehata, Heba Sh. (2008) Enhancement of nitrogen fixation, growth and productivity of Bradyrhizobium-lupin symbiosis via co-inoculation with rhizobacteria in different soil types. J. Agric. Sci., Mansoura Univ. 33, 469-484.

Ali, Laila K. M. and Mostafa, Soha S. M. (2009) Evaluation of potassium humate and Spirulina platensis as a bio-organic fertilizer for sesame plants grown under salinity stress. Egypt. J. Agric. Res. 87, 369-388.

A.O.A.C. (1990) "Official Methods of Analysis" of the Association of Official Agricultural Chemists. $15^{\text {th }}$ ed., published by A.O.A.C.

Atlas, R. M. (1995) “Handbook of Media for Environmental Microbiology”. CRC Press, Boca Raton, FL.

Bai, Y., Souleimanov, A. and Smith, D.L. (2002) An inducible activator produced by Serratia proteamaclans strain and its soybean growth promoting activity under greenhouse conditions. J. Exp.Bot. 53,149-502.

Desoky, A.H., El-Sawy, W.A. and Taher, H.M.E. (2011) Enhancement of peanut growth and productivity by inoculation with Bradyrhizobium and some rhizobacteria under graded levels of mineral N-fertilization in newly soils. Egypt. J. Appl. Sci. 26, 409-427.

Dey, R., Pal, K. K., Bhatt, D.M. and Chauhan, S. M. (2004) Growth promotion and yield enhancement of peanut, (Arachis hypogaea L.) by application of growthpromoting rhizobacteria. Micbiol. Res.159, 371-394.

Dileep-Kumar, B.S., Berggren, I. and Martensson, A.M. (2001) Potential for improving pea production by co-inoculation with Pseudomonas fluorescens and Rhizobium. Plant and Soil, 229, 25-34.

El-Ghamry, A. M., Kamar, M. A. A. and Khalid, M. G. (2009) Amino and humic acids promote growth, yield and disease resistance of. faba bean cultivated in clay soil. Aust. J. Basic and Appl. Sci. 3, 731-739.

El-Kramany, M.F., Bahr, Amany A., Mohamed, Manal F. and Kabesh, M.O. (2007) Utilization of bio-fertilizers in field crops production 16-groundnut yield, its 
components and seeds content as affected by partial replacement of chemical fertilizers by bio-organic fertilizers. J. Appl. Sci. Res. 3, 25-29.

El-Sawi, W.A., Mekhemar, G.A.A. and Kandil, B.A.A. (2006) Comparative assessment of growth and yield responses to two peanut genotypes to inoculation with Bradyrhizobium conjugated with cyanobacteria or rhizobacteria. Minufiya. J.Agric. Res. 31,1031-1049.

Fageria, N. K., Ballgar, V. C. and Johnes, C.A. (1997) "Growth and Mineral Mutrition of Field Crops". $2^{\text {nd }}$ ed. Marcel Dekker. Inc, New York, U.S.A. p:494.

Gupta, A., Saxena, A.K., Murali, G., Tilak, K.V. and Godal, M. (2003) Effects of co-inoculation of plant-growth promoting rhizobacteria and Bradyrhizobium sp. (Vigna) on the growth and yield of green gram [Vigna radiata (L.) Wilczek]. Trop. Agric. 80, 28-35.

Mekhemar, G.A.A., Ismail, F.M., Badawi, F.Sh.F. and Kandil, B.A.A. (2007) Response of Peanut (Arachis hypogaea L.) to co-inoculation with Bradyrhizobium spp. and phosphate dissolving bacteria under different levels of phosphorus fertilization in sandy soils. Agric. Res. J., Suez Canal Univ. 7,1-8.

Page,A.L., Miller, R.H. and Keeney, D.R. (1982) "Methods of Soil Analysis".IIChemical and Microbiological Properties.Soil Amer., Madison Wisconsin, USA.

Piper, C.S. (1950) "Soil and Plant Analysis". $1^{\text {st }}$ ed.Interscience Publishers Inc., New York, pp.30-229.

Saruhan, V., Kusvuran, A. and Kokten, K. (2011) The effect of different replication of humic acid fertilization on yield performance of common vetch (Vicia sativa L.). African Biotechn.10,5587-5592.

Shehata, S. A. and EL-Helaly, M.A. (2010) Effect of compost, humic acid and amino acids on yield of snap beans. J. Hort. Sci. and Ornaman. Plants, 2, 107-110.

Snedecor, G.W. and Cochran, W.G. (1980) "Statistical Methods" $7^{\text {th }}$ ed., Iowa State Univ. Press, Ames., SA, pp. 255-269.

Suganya, S. and Sivasamy, R. (2006) Moisture retention and cation exhange capacity of sandy soil as influenced by soil additives I. Appl Sci. Res. 2, 949-951.

Tilak, K.V.B.R., Ranganayaki, N., Pal, K.K., De, R., Saxena, A.K., Shekhar Nautiyal, C., Shilpi, M., Tripathi, A.K. and Tohri, B.N. (2005) Diversity of plant growth and soil health supporting bacteria. Current Sci. 89, 136-150.

Vargas, L.K., Lisboa, B.B., Schlindwein, G., Granada, C. E., Giongo, A., Beneduzi, A. and Luciane-Maria, P. Passaglia (2009) Occurrence of plant growth-promoting traits in clover-nodulating rhizobia strains isolated from different soils in rio grande do sul state. R. Bras. Ci. Solo. 33,1227-1235.

Vincent, J. M. (1970) "A Manual for the Partical Study of the Root Nodule Bacteria". IBP Handbook, No. 15, Blackwell. 


\section{تحسين إنتاجية الفول السودانى عن طريق التلقيح بالبرادى ريزوبييم

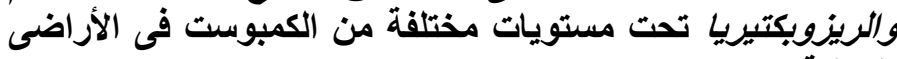

توكل يونس رززق، عزت محمد سليمان" ، فيصل إسماعيل العربى *وهالة عبد

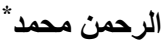

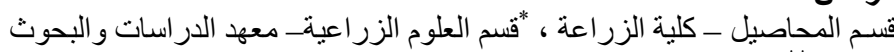

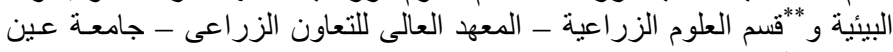
شمس - القاهرة - مصر.

أجريت تجربتين حقليتين فى المزرعة البحثية الخاصة بالمعهة العالى للتعاون

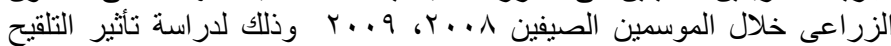
البكتيرى بالبرادى ريزوبيم Bradyrhizobium إما بصورة منفردة الو أو بالأشتر اك الك

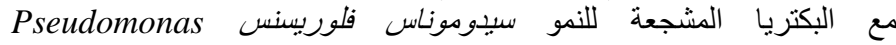
fluorescens

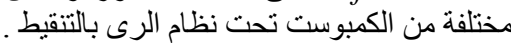

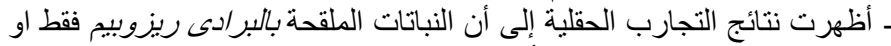

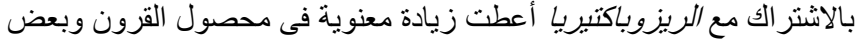
مكونات الحاصل مقارنة بالنباتات غير العير الملقدة.

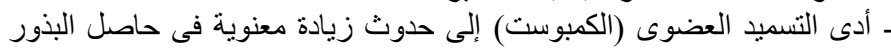

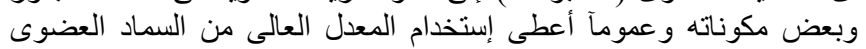

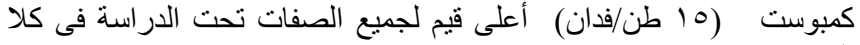

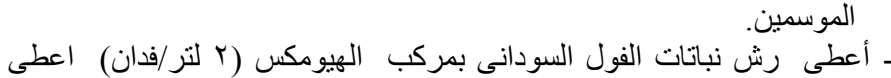

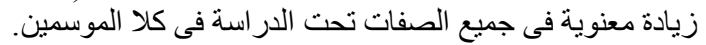

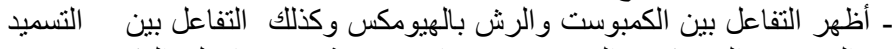

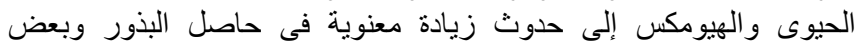

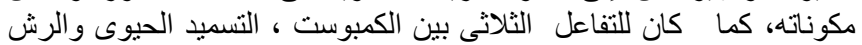

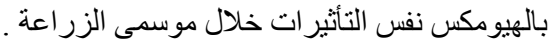

